\title{
The Identification of the structures new type Al-Si-Mg Ca alloys with different Ca content using of the color metallography
}

\section{Elena Střihavková, Viktorie Weiss}

Faculty of Production Technology and Management, UJEP in Ústí nad Labem E-mail: strihavkova@fvtm.ujep.cz.

This paper presents some analysis of color metallography in the identification new structures of aluminium alloys. For experimental purposes aluminium alloy from the group hypereutectic AlSi7Mg 0,3 silumins was used. Alloy and modified using calcium in the form of master alloy AlCa10. The master alloy AlCa10 in the analyzed alloys added to improve the technological properties af alumium alloys, especially fluidity and machinability while maintaining sufficient corrosion resistance of the alloy. The analysis and evaluation of individual structural components are used method of color etching. The analyzed alloy was also subjected to the method of the black and with contrast what, but not of this paper subject. The application of color metallography is possible to differentiate and identify the presence of the intermetallic particles with different chemical composition.

Keywords: aluminum structure, color contrast, alloys, addition alloys, etching.

\section{Acknowledgement}

This article was created by the specifics research of JEPU.

\section{References}

[1] MICHNA, Š., LUKÁČ, I., OČENÁŠEK, V., KOŘENÝ, R., a kol.: Encyklopedie hliníku, ISBN 80-89041-88-4, Adin s.r.o. 2005

[2] BOLIBRUCHOVÁ, D., TILlOVÁ: Zlievarenské zliatiny Al-Si, ŽU v Žiline - EDIS, 2005, ISBN 80-8070-4856.

[3] ABDOLLAHI, A., GRUZLESKI, J.E.: Cast Metals, 1998, č. 1, s. 145-155.

[4] LUKÁČ, I., GRUTKOVÁ, J.: Vlastnosti a štruktúra neželezných kovov II, Alfa 1975.

[5] MONDOLFO, L.F.. Aluminium Alloys, Structure and Properties, Butterworths, London 1979.

[6] LUKÁČ, I., MICHNA, Š.: Colour kontrast, structure and defects in aluminium and aluminium alloy, Cambridge Intermational Science Publishing, 2001, ISBN 1898326703.

[7] KUCHǍ̌, L., DRÁPALA, J.: Bojary systéme of aluminium - admixture and thein importace for metallurgy, Ostrava, 2003, ISBN 80-239-1469-3.

[8] MICHNA, Š., KUŠMIERCZAK, S., BAJCURA, M.: Metalografie: Metody a postupy, 1. vyd. Prešov, 2010, ISBN 978-80-89244-74-7.

[9] HIDEYUKI, U., a kol.: Interdendritic Fluid Flow i in Al-7\%Si Alloys Modified with Sodium and Antimony., Cast Metals, Volume 8, 1994, č. 1. s. 7-11.

[10] KORITTA, J., HOLEĆEK, S., FRANÉK, A.: Současné názory na modifikaci slitin Al-Si a používané modifikační postupy., Slévárenství, 1971, č.3/4, s. 91.

[11] WANG, L., MAKHLOUF, M., APELIAN, D.: Aluminium die casting alloys: alloy composition, microstructure and properties - performance relationships., International Materiále Reviews, 1995, 6, s. 221.

[12] MICHNA, Š.: Strukturální analýza a vlastnosti předslitiny AlCa10, Strojírenská technologie, 2010, s. 175-176.

Paper number: M201251 